\title{
The Pilling-Bedworth Ratio of Oxides Formed From the Precipitated Phases in Magnesium Alloys
}

\author{
Quantong Jiang ${ }^{1,2,3 *}$, Dongzhu Lu ${ }^{1,2,3}$, Chang Liu ${ }^{1,2,3}$, Nazhen Liu ${ }^{1,2,3 *}$ and Baorong Hou ${ }^{1,2,3}$ \\ ${ }^{1}$ CAS Key Laboratory of Marine Environmental Corrosion and Bio-Fouling, Institute of Oceanology, Chinese Academy of \\ Sciences, Qingdao, China, ${ }^{2}$ Open Studio for Marine Corrosion and Protection, Pilot National Laboratory for Marine Science and \\ Technology (Qingdao), Qingdao, China, ${ }^{3}$ School of Materials Science and Engineering, Qilu University of Technology, Jinan, \\ China
}

The Pilling-Bedworth ratio of oxides preferentially formed from the precipitated phases in magnesium alloys were calculated. The results showed that the PBR value of $\mathrm{Nd}_{2} \mathrm{O}_{3}$ preferentially formed from $\mathrm{Mg}_{12} \mathrm{Nd}$ was 1.0584, and the PBR value of $\mathrm{Y}_{2} \mathrm{O}_{3}$ preferentially formed from $\mathrm{Mg}_{24} \mathrm{Y}_{5}$ was 1.1923. Both the $\mathrm{Nd}_{2} \mathrm{O}_{3}$ and $\mathrm{Y}_{2} \mathrm{O}_{3}$ would provide a good protection to the $\mathrm{Mg}$ matrix. The $\mathrm{Gd}_{2} \mathrm{O}_{3}$ preferentially formed from $\mathrm{Mg}_{3} \mathrm{Gd}$, whereas the $\mathrm{MgO}$ preferentially formed from $\mathrm{MgNi}_{2}$. The PBR value of these two oxides were both larger than 2. The corresponding oxides formed from the common precipitated phases $\mathrm{Mg}_{17} \mathrm{Al}_{12}, \mathrm{MgZn}_{2}, \mathrm{MgCu}_{2}, \mathrm{Mg}_{2} \mathrm{Ca}, \mathrm{Mg}_{12} \mathrm{Ce}$, and $\mathrm{MgAg}$ were all less than 1. The oxide films formed on surfaces of pure $\mathrm{Mg}$ and $\mathrm{Mg}-\mathrm{xY}(x=3,5,7 \mathrm{wt} . \%)$ alloys at high temperatures were analyzed. The results showed that the oxide films were composed of a $\mathrm{Y}_{2} \mathrm{O}_{3} / \mathrm{MgO}$ outer layer and an inner layer rich with $\mathrm{Y}_{2} \mathrm{O}_{3}$. The formation of $\mathrm{Y}_{2} \mathrm{O}_{3}$ was mainly caused by the oxidation of $\mathrm{Mg}_{24} \mathrm{Y}_{5}$. The more $\mathrm{Y}_{2} \mathrm{O}_{3}$ existed in the composite oxidation film, the better corrosion resistance of the $\mathrm{Mg}-\mathrm{Y}$ samples.

Keywords: oxide, PBR value, magnesium alloys, precipitated phases, Mg-Y

\section{INTRODUCTION}

The PBR (Pilling-Bedworth Ratio) value of oxide film is an important parameter to evaluate the film protection performance to the base metal (Xu and Gao, 2000). When the PBR value is less than 1, the protection performance of the oxide film is poor, due to the existing tensile stress and the resultant incomplete coverage of the oxide film to the metal. Similarly, when the PBR value is larger than 3 , the oxide film also shows a weak protection, due to the compressive stress in the film. When the PBR value is between 1 and 2, the oxide film is protective (Bradford 1993; Tan et al., 2016; Song et al., 2021).

Magnesium is active, so the $\alpha$-Mg matrix and precipitated phases in magnesium alloys are prone to be oxidized in the atmospheric environment (Czerwinski 2002; Liu et al., 2009; Medved et al., 2009), leading to the formation of different kinds of oxidation films on the magnesium alloy surface (Czerwinski, 2012; Czerwinski, 2015). The PBR value of oxidation film formed on pure magnesium is about 0.8 , which is not protective (You et al., 2000; Mebarki et al., 2005; Cheng et al., 2009; López et al., 2010).

There are many precipitated phases existing in magnesium alloys, including $\mathrm{Mg}_{17} \mathrm{Al}_{12}, \mathrm{MgZn}_{2}$, $\mathrm{Mg}_{2} \mathrm{Ca}, \mathrm{Mg}_{5} \mathrm{Gd}, \mathrm{Mg}_{12} \mathrm{Nd}$ and $\mathrm{Mg}_{24} \mathrm{Y}_{5}$, etc., (Nie 2012; Zhu and Chen, 2019; Kaya, 2020; Shi et al., 2020). The crystallography of the precipitated phases determines the microstructure and property of magnesium alloys. According to the literatures, the film formed by oxidation of precipitated phases during the heat treatment process, has good corrosion resistance (Sudholz et al., 2011; Chang et al., 
TABLE 1 | Absolute atomic mass of different alloying elements.

\begin{tabular}{|c|c|c|c|c|c|c|}
\hline Atomic species & $c^{12}$ & $\mathbf{M g}$ & Al & $\mathrm{Zn}$ & $\mathrm{Cu}$ & $\mathbf{C a}$ \\
\hline Relative mass & 12.017 & 24.305 & 26.982 & 65.409 & 63.546 & 40.078 \\
\hline Absolute mass $/ 10^{-26} \mathrm{Kg}$ & 1.9927 & 4.0303 & 4.4742 & 10.846 & 10.537 & 6.6450 \\
\hline Atomic species & Gd & Nd & $\mathrm{Ce}$ & Ag & $\mathrm{Ni}$ & $\mathbf{Y}$ \\
\hline Relative mass & 157.25 & 144.242 & 140.116 & 107.868 & 58.693 & 88.905 \\
\hline Absolute mass $/ 10^{-26} \mathrm{Kg}$ & 26.0757 & 23.9187 & 23.2345 & 17.887 & 9.733 & 14.7425 \\
\hline
\end{tabular}

2015; Yu et al., 2015). Due to the different activity of alloying elements, the property of oxide film formed from the precipitated phases in the atmospheric environment is different (Van Orman and Crispin, 2010). PBR is the ratio of oxide volume consisting metal and oxygen on the metal surface, to the volume of base metal atoms, which reflects the stress condition in the oxide film. The corrosion tendency of magnesium alloy is closely related to the conditions of the oxide layer (Wang et al., 2007; Fan et al., 2011).

In this work, the PBR values of oxides formed from the precipitated phases in magnesium alloys were calculated. In order to verify the PBR calculation results of oxides formed from the precipitated phases in magnesium alloys, the morphologies of oxidation films formed on the surfaces of pure $\mathrm{Mg}$ and $\mathrm{Mg}-\mathrm{xY}$ alloys $(x=3,5,7 \mathrm{wt} . \%)$ at high temperature were characterized. The effect of the oxidation films on corrosion resistance were also studied. This work is expected to give a scientific and reasonable method to improve intrinsic corrosion resistance of magnesium alloys by regulating the types of precipitates.

\section{CALCULATION OF THE PILLING-BEDWORTH RATIO VALUE}

\section{Calculation of Absolute Atomic Mass}

The relative atomic mass values of the alloying elements, including $\mathrm{Al}, \mathrm{Zn}, \mathrm{Cu}, \mathrm{Ca}, \mathrm{Gd}, \mathrm{Nd}, \mathrm{Ce}, \mathrm{Ag}, \mathrm{Ni}, \mathrm{Y}$ and $\mathrm{C}^{12}$ were obtained from the periodic table of elements. The absolute atomic mass values of the alloying elements were calculated via the following formula:

$\begin{aligned} \text { Absolute tomic mass }= & \frac{\text { Relative atomic mass of alloying elements }}{\text { Relative atomic mass of C12 }} \\ & \times 1.9927 \times 10^{-26} \mathrm{Kg}\end{aligned}$

The results were shown in Table $\mathbf{1}$.

\section{Molar Volume of Precipitated Phases $M_{A} X_{B}$ in Magnesium Alloys}

The crystal structure and parameters of the common precipitated phases in the magnesium alloys, including $\mathrm{Mg}_{17} \mathrm{Al}_{12}, \mathrm{MgZn}_{2}$,
$\mathrm{MgCu}_{2}, \mathrm{Mg}_{2} \mathrm{Ca}, \mathrm{Mg}_{3} \mathrm{Gd}, \mathrm{Mg}_{12} \mathrm{Nd}, \mathrm{Mg}_{12} \mathrm{Ce}, \mathrm{MgAg}, \mathrm{MgNi}_{2}$ and $\mathrm{Mg}_{24} \mathrm{Y}_{5}$ were obtained by the phase diagram.

The atom number in a single unit cell of the precipitated phases $\mathrm{Mg}_{\mathrm{A}} \mathrm{X}_{\mathrm{B}}$ was calculated via the crystal structure. For example, the crystal structure of $\mathrm{Mg}_{24} \mathrm{Y}_{5}$ is body-centered cubic (BCC), so there are two $\mathrm{Mg}_{24} \mathrm{Y}_{5}$ intermetallics in each unit cell. The total atom number in a single $\mathrm{Mg}_{24} \mathrm{Y}_{5}$ unit cell is $2 \times(24 \mathrm{Mg}+5 \mathrm{Y})=48 \mathrm{Mg}+$ 10Y. The absolute mass of a single $\mathrm{Mg}_{24} \mathrm{Y}_{5}$ unit cell (the sum of $48 \mathrm{Mg}$ atoms and $10 \mathrm{Y}$ atoms) was obtained as following: $48 \times$ $4.0303 \times 10^{-23} \mathrm{~g}+10 \times 14.7425 \times 10^{-23} \mathrm{~g}=340.8794 \times 10^{-23} \mathrm{~g}$. The absolute mass of other single precipitated phases $\mathrm{Mg}_{\mathrm{A}} \mathrm{X}_{\mathrm{B}}$ was calculated via the same method with results shown in Table 2.

The volume of a single unit cell was calculated according to the crystal structure and parameters obtained from the XRD card. The density of a single unit cell was calculated via the following formula:

$$
\text { Density of a single unit cell }=\frac{\text { Absolute mass of a single unit cell }}{\text { Volume of a single unit cell }}
$$

The $\mathrm{Mg}_{24} \mathrm{Y}_{5}$ unit cell is body-centered cubic (BCC) structure, and the lattice parameters is $\mathrm{a}=1.1257 \times 10^{-7} \mathrm{~cm}$. So the Volume of a single unit cell is $\mathrm{a}^{3}=\left(1.1257 \times 10^{-7} \mathrm{~cm}\right)^{3}=1.4265 \times$ $10^{-21} \mathrm{~cm}^{3}$, the density of a single $\mathrm{Mg}_{24} \mathrm{Y}_{5}$ unit cell is $\frac{340.8794 \times 10^{-23} \mathrm{~g}}{1.4265 \times 10^{-21} \mathrm{~cm}^{3}}=2.3896 / \mathrm{cm}^{3}$, according to Eq. 2. The densities of single unit cells of the other precipitated phases were obtained via the same method. The density of a single $\mathrm{Mg}_{24} \mathrm{Y}_{5}$ unit cell is the density of the $\mathrm{Mg}_{24} \mathrm{Y}_{5}$ intermetallics.

The molar volume of precipitated phases $\mathrm{Mg}_{\mathrm{A}} \mathrm{X}_{\mathrm{B}}$ in magnesium alloys was calculated via the formula as follow:

$$
\begin{gathered}
\text { Molar volume of precipituated phases } \\
=\frac{\text { Molarmassof precipitated phases }}{\text { Densityof asingleMgAXBunitcell }}
\end{gathered}
$$

For example, the molar volume of $\mathrm{Mg}_{24} X_{5} \frac{1027.845}{2.3896}=430.132 \mathrm{~cm}^{3}$. All the calculated results are shown in Table 2.

\section{Pilling-Bedworth Ratio Calculation of Oxidation Formed From Precipitated Phases}

According to the formation Gibbs energies of the metal's oxides (James 2005), the preferential metal atom of the precipitated 
TABLE 2 | Molar volume of precipitated phases $\operatorname{Mg}_{A} X_{B}$ in magnesium alloys.

\begin{tabular}{|c|c|c|c|c|c|c|c|c|}
\hline \multirow{2}{*}{$\begin{array}{l}\text { Precipitated } \\
\text { phases }\end{array}$} & \multirow{2}{*}{$\begin{array}{l}\text { Crystal } \\
\text { structure }\end{array}$} & \multicolumn{5}{|c|}{ A single unit cell of precipitated phases MgAXB } & \multirow{2}{*}{$\begin{array}{l}\text { Molar } \\
\text { mass }\end{array}$} & \multirow{2}{*}{$\begin{array}{c}\text { Molar } \\
\text { volume }\end{array}$} \\
\hline & & $\begin{array}{c}\text { Number of } \\
\text { atoms }\end{array}$ & $\begin{array}{l}\text { Mass/ } \\
10^{-23} \mathrm{~g}\end{array}$ & $\begin{array}{c}\text { Lattice } \\
\text { parameters }\end{array}$ & $\begin{array}{c}\text { Volume } \\
10^{-21} \mathrm{~cm}^{3}\end{array}$ & $\begin{array}{c}\text { Density } \\
\text { g/cm }{ }^{3}\end{array}$ & & \\
\hline $\mathrm{Mg}_{24} \mathrm{Y}_{5}$ & $\mathrm{BCC}$ & $48+10$ & 340.8794 & $a=1.1257$ & 1.4265 & 2.3896 & $1,027.845$ & 430.132 \\
\hline $\mathrm{Mg}_{3} \mathrm{Gd}$ & FCC & $12+4$ & 152.6664 & $a=0.7326$ & 0.3932 & 3.8828 & 230.165 & 59.2781 \\
\hline $\mathrm{Mg}_{12} \mathrm{Ce}$ & $\mathrm{BCC}$ & $24+2$ & 143.1962 & $\begin{array}{c}a=1.033 \mathrm{c}= \\
0.5964\end{array}$ & 0.6364 & 2.2501 & 431.776 & 191.892 \\
\hline $\mathrm{Mg}_{12} \mathrm{Nd}$ & $\mathrm{BCC}$ & $4+2$ & 144.5646 & $a=1.031 c=0.593$ & 0.6303 & 2.297 & 435.902 & 189.770 \\
\hline $\mathrm{Mg}_{17} \mathrm{Al}_{12}$ & $\mathrm{BCC}$ & $34+24$ & 244.411 & $a=1.056$ & 1.1776 & 2.078 & 736.969 & 354.653 \\
\hline $\mathrm{MgZn}_{2}$ & $\mathrm{HCP}$ & $2+4$ & 51.4458 & $\begin{array}{l}a=0.5222 \\
c=0.8568\end{array}$ & 0.6075 & 4.960 & 155.123 & 31.275 \\
\hline $\mathrm{MgCu}_{2}$ & FCC & $4+8$ & 100.4204 & $a=0.7048$ & 0.3415 & 5.745 & 151.397 & 25.880 \\
\hline $\mathrm{Mg}_{2} \mathrm{Ca}$ & $\mathrm{HCP}$ & $4+2$ & 29.4130 & $a=0.623 c=1.012$ & 1.0212 & 1.732 & 88.688 & 51.206 \\
\hline $\mathrm{MgAg}$ & SC & $1+1$ & 21.9173 & $a=0.3314$ & 0.0364 & 6.030 & 132.173 & 21.919 \\
\hline $\mathrm{MgNi}_{2}$ & $\mathrm{HCP}$ & $2+4$ & 46.9914 & $\begin{array}{l}a=0.4824 \\
c=1.5826\end{array}$ & 0.9575 & 5.902 & 107.303 & 18.181 \\
\hline
\end{tabular}

phases $\mathrm{Mg}_{\mathrm{A}} \mathrm{X}_{\mathrm{B}}$ in magnesium alloys during oxidation reaction in the atmospheric environment were:

1) $\Delta_{\mathrm{f}} \mathrm{G}^{\circ} \mathrm{Al}_{2} \mathrm{O}_{3}=-38.5 \mathrm{~kJ} / \mathrm{mol}>\Delta_{\mathrm{f}} \mathrm{G}^{\circ} \mathrm{MgO}=-135.27 \mathrm{~kJ} / \mathrm{mol}$; $\mathrm{Mg}_{17} \mathrm{Al}_{12} \rightarrow \mathrm{Mg} \rightarrow \mathrm{MgO}$

2) $\Delta_{\mathrm{f}} \mathrm{G}^{\circ} \mathrm{ZnO}=-76.08 \mathrm{~kJ} / \mathrm{mol}>\Delta_{\mathrm{f}} \mathrm{G}^{\circ} \mathrm{MgO}=-135.27 \mathrm{~kJ} / \mathrm{mol}$; $\mathrm{MgZn}_{2} \rightarrow \mathrm{Mg} \rightarrow \mathrm{MgO}$

3) $\Delta_{\mathrm{f}} \mathrm{G}^{\circ} \mathrm{CuO}=-31.0 \mathrm{~kJ} / \mathrm{mol}>\Delta_{\mathrm{f}} \mathrm{G}^{\circ} \mathrm{MgO}=-135.27 \mathrm{~kJ} / \mathrm{mol}$; $\mathrm{MgCu}_{2} \rightarrow \mathrm{Mg} \rightarrow \mathrm{MgO}$

4) $\Delta_{\mathrm{f}} \mathrm{G}^{\circ} \mathrm{CaO}=-144.25 \mathrm{~kJ} / \mathrm{mol}<\Delta_{\mathrm{f}} \mathrm{G}^{\circ} \mathrm{MgO}=-135.27 \mathrm{~kJ} / \mathrm{mol}$; $\mathrm{Mg}_{2} \mathrm{Ca} \rightarrow \mathrm{Ca} \rightarrow \mathrm{CaO}$

5) $\Delta_{\mathrm{f}} \mathrm{G}^{\circ} \mathrm{Gd}_{2} \mathrm{O}_{3}=-434.9 \mathrm{~kJ} / \mathrm{mol}<\Delta_{\mathrm{f}} \mathrm{G}^{\circ} \mathrm{MgO}=-135.27 \mathrm{~kJ} / \mathrm{mol}$; $\mathrm{Mg}_{3} \mathrm{Gd} \rightarrow \mathrm{Gd} \rightarrow \mathrm{Gd}_{2} \mathrm{O}_{3}$

6) $\Delta_{\mathrm{f}} \mathrm{G}^{\circ} \mathrm{Nd}_{2} \mathrm{O}_{3}=-411.3 \mathrm{~kJ} / \mathrm{mol}<\Delta_{\mathrm{f}} \mathrm{G}^{\circ} \mathrm{MgO}=-135.27 \mathrm{~kJ} / \mathrm{mol}$; $\mathrm{Mg}_{12} \mathrm{Nd} \rightarrow \mathrm{Nd} \rightarrow \mathrm{Nd}_{2} \mathrm{O}_{3}$

7) $\Delta_{\mathrm{f}} \mathrm{G}^{\circ} \mathrm{Ce}_{2} \mathrm{O}_{3}=-407.80 \mathrm{~kJ} / \mathrm{mol}<\Delta_{\mathrm{f}} \mathrm{G}^{\circ} \mathrm{MgO}=-135.27 \mathrm{~kJ} / \mathrm{mol}$; $\mathrm{Mg}_{12} \mathrm{Ce} \rightarrow \mathrm{Ce} \rightarrow \mathrm{Ce}_{2} \mathrm{O}_{3}$

8) $\Delta_{\mathrm{f}} \mathrm{G}^{\circ} \mathrm{Ag}_{2} \mathrm{O}=-2.68 \mathrm{~kJ} / \mathrm{mol}>\Delta_{\mathrm{f}} \mathrm{G}^{\circ} \mathrm{MgO}=-135.27 \mathrm{~kJ} / \mathrm{mol}$; $\mathrm{MgAg} \rightarrow \mathrm{Mg} \rightarrow \mathrm{MgO}$

9) $\Delta_{\mathrm{f}} \mathrm{G}^{\circ} \mathrm{NiO}=-50.6 \mathrm{~kJ} / \mathrm{mol}>\Delta_{\mathrm{f}} \mathrm{G}^{\circ} \mathrm{MgO}=-135.27 \mathrm{~kJ} / \mathrm{mol}$; $\mathrm{MgNi}_{2} \rightarrow \mathrm{Mg} \rightarrow \mathrm{MgO}$

10) $\Delta_{\mathrm{f}} \mathrm{G}^{\circ} \mathrm{Y}_{2} \mathrm{O}_{3}=-434.19 \mathrm{~kJ} / \mathrm{mol}<\Delta_{\mathrm{f}} \mathrm{G}^{\circ} \mathrm{MgO}=-135.27 \mathrm{~kJ} / \mathrm{mol}$; $\mathrm{Mg}_{24} \mathrm{Y}_{5} \rightarrow \mathrm{Y} \rightarrow \mathrm{Y}_{2} \mathrm{O}_{3}$

If there is one type of precipitated phase $A_{U} B_{V}$ in magnesium alloy, the preferentially oxidized element is $\mathrm{B}$-content in the $A_{U} B_{V}$ single unit cell. Because the preferentially oxidized $\mathrm{B}$-content is derived from $\mathrm{A}_{U} B_{V}$, which is a solid solution structure. Therefore, the volume of $\mathrm{B}$-content can be obtained from the volume of $A_{U} B_{V}$ single unit cell subtracted the volume of unoxidized A-content ( $\mathrm{Xu}$ and Gao, 2000), as shown by the following formula,

Volume of $x_{B}=$ Volume of $\left[(\mathbf{X} / \mathbf{V})_{\mathrm{AuBv}}\right]-$ Volume of $\left[(u x / v)_{A}\right]$

For example, the molar volume of $\mathrm{Y}$ atom in $\mathrm{Mg}_{24} \mathrm{Y}_{5}$ unit cell was calculated via: $1 / 5\left[V_{\mathrm{Mg}_{24} \mathrm{Y}_{5}}-24 V_{\mathrm{Mg}}\right]=$ $1 / 5 \times[430.132-24 \times 13.9845] \mathrm{cm}^{3}=18.9008 \mathrm{~cm}^{3}$. In consideration of $\mathrm{x}$ in Eq. 6 ( 2 for $\mathrm{Y}_{2} \mathrm{O}_{3}$ ), the volume of $2 \mathrm{~mol}$ of $\mathrm{Y}$ in alloy is calculated by $2 \times 18.9008 \mathrm{~cm}^{3}=37.8016 \mathrm{~cm}^{3}$.

Then, the density and molar mass of oxide product can be obtained via periodic table of elements. Thus, the molar volume of oxidized product can be calculated via the formula:

$$
\text { Molarvolumeofoxide }=\frac{\text { Molarmasso foxideproduct }}{\text { Densityofoxideproduct }}
$$

For example, the molar volume of oxide product $\mathrm{Y}_{2} \mathrm{O}_{3}$ from the oxidation of precipitated phases $\mathrm{Mg}_{24} \mathrm{Y}_{5}$ was calculated as follow: $\frac{M_{Y_{2} \mathrm{O}_{3}}}{\mathrm{D}_{\mathrm{Y}_{2} \mathrm{O}_{3}}}=\frac{225.81 \mathrm{~g} / \mathrm{mol}}{5.01 \mathrm{~g} / \mathrm{cm}^{3}}=45.0719$.

The PBR value of oxidation films formed from the precipitated phases in magnesium alloys was calculated via the formula:

$$
P B R_{\text {precipitated phases }} \frac{\text { Volumeo fonemoleof } B_{x} O_{y}}{\text { Volume of } x \text { moles of } B \text { in alloy }}
$$

All the results were shown in Table 3.

\section{Characteristic of Oxide Films on the Mg-xY $(x=3,5,7$ wt. $\%)$ Alloys Surfaces}

Commercially pure $\mathrm{Mg}$ (99.9 wt. \%), Mg- 3Y wt.\%, Mg- 5Y wt.\% and $\mathrm{Mg}-7 \mathrm{Y}$ wt.\% were used to characterize the oxide film on the surface of magnesium alloys. The samples with dimensions of $1 \mathrm{~cm} \times$ $1 \mathrm{~cm} \times 1 \mathrm{~cm}$ were heated in the dry air at $400^{\circ} \mathrm{C}$ for $36 \mathrm{~h}$. These samples were used to analyze the microstructure of oxide films, including the morphologies, thicknesses and compositions by scanning electron microscopy (SEM) and energy dispersive spectroscopy (EDS). The samples with dimensions of $2 \mathrm{~cm} \times 2 \mathrm{~cm}$ $\times 0.5 \mathrm{~cm}$ were also heated in dry air at $400^{\circ} \mathrm{C}$ for $36 \mathrm{~h}$, which were used to test the open circuit potential (OCP) using the electrochemical workstation. Three parallel samples were used to ensure the accuracy of the test results. All the samples were polished with 1,000, 3,000 and $5,000 \# \mathrm{SiC}$ papers and then cleaned with absolute ethanol.

Due to the affinity of oxygen to magnesium alloys, samples are oxidized rapidly at a high temperature in dry air. The rate of oxidation increases first linearly, then exponentially with the 
TABLE 3 | PBR value of the oxide film formed from the precipitated phases of magnesium alloys.

\begin{tabular}{|c|c|c|c|c|c|c|c|c|}
\hline \multirow{2}{*}{$\begin{array}{l}\text { Precipitated } \\
\text { phases } \\
\mathrm{Mg}_{A} \mathrm{X}_{\mathrm{B}} \text { in } \\
\text { magnesium alloys }\end{array}$} & \multirow[t]{2}{*}{$\begin{array}{c}\operatorname{Mg}_{A} X_{B} \\
\text { Volume/cm }\end{array}$} & \multicolumn{2}{|c|}{$\begin{array}{c}\text { The lower metal activity } \\
\text { element in } \operatorname{Mg}_{A} X_{B}\end{array}$} & \multirow{2}{*}{$\begin{array}{l}\text { The molar } \\
\text { volume of } \\
\text { the preferentially } \\
\text { oxidized } \\
\text { metal } / \mathrm{cm}^{3}\end{array}$} & \multicolumn{3}{|c|}{ Preferentially oxidized product } & \multirow{2}{*}{$\begin{array}{l}\text { PBR value } \\
\text { of oxidation } \\
\text { films } \\
\text { formed } \\
\text { from } \mathrm{Mg}_{A} X_{B}\end{array}$} \\
\hline & & $\begin{array}{l}\text { Density } \\
\text { (g/cm3) }\end{array}$ & $\begin{array}{l}\text { Volume/ } \\
\mathrm{cm}^{3}\end{array}$ & & Molar mass & $\begin{array}{l}\text { Density } \\
\text { g/cm }{ }^{3}\end{array}$ & $\begin{array}{l}\text { Volume/ } \\
\mathrm{cm}^{3}\end{array}$ & \\
\hline $\mathrm{Mg}_{24} \mathrm{Y}_{5}$ & 430.132 & $\mathrm{Mg}=1.738$ & 13.9845 & $Y=37.8016$ & Y2O3 = 225.81 & 5.01 & 45.0719 & 1.1923 \\
\hline $\mathrm{Mg}_{3} \mathrm{Gd}$ & 59.2781 & $\mathrm{Mg}=1.738$ & 13.9845 & $\mathrm{Gd}=17.3246$ & $\begin{array}{c}\mathrm{Gd} 2 \mathrm{O} 3= \\
362.49\end{array}$ & 7.41 & 48.9201 & 2.8237 \\
\hline $\mathrm{Mg}_{12} \mathrm{Ce}$ & 191.892 & $\mathrm{Mg}=1.738$ & 13.9845 & $\mathrm{Ce}=48.156$ & $\begin{array}{c}\mathrm{Ce} 2 \mathrm{O} 3= \\
328.24\end{array}$ & 7.13 & 46.0365 & 0.9560 \\
\hline $\mathrm{Mg}_{12} \mathrm{Nd}$ & 189.770 & $\mathrm{Mg}=1.738$ & 13.9845 & $\mathrm{Nd}=43.912$ & $\begin{array}{c}\mathrm{Nd} 2 \mathrm{O} 3= \\
336.47\end{array}$ & 7.24 & 46.4738 & 1.0584 \\
\hline $\mathrm{Mg}_{17} \mathrm{Al}_{12}$ & 354.653 & $\mathrm{Al}=2.70$ & 9.9933 & $\mathrm{Mg}=13.8078$ & $\mathrm{MgO}=40.304$ & 3.65 & 11.042 & 0.7997 \\
\hline $\mathrm{MgZn}_{2}$ & 31.275 & $\mathrm{Zn}=7.14$ & 9.1609 & $\mathrm{Mg}=12.9532$ & $\mathrm{MgO}=40.304$ & 3.65 & 11.042 & 0.8525 \\
\hline $\mathrm{MgCu}_{2}$ & 25.880 & $\mathrm{Cu}=8.96$ & 7.0922 & $\mathrm{Mg}=11.6956$ & $\mathrm{MgO}=40.304$ & 3.65 & 11.042 & 0.9441 \\
\hline $\mathrm{Mg}_{2} \mathrm{Ca}$ & 51.206 & $\mathrm{Mg}=1.738$ & 13.9845 & $\mathrm{Ca}=23.237$ & $\mathrm{CaO}=56.077$ & 3.25 & 17.254 & 0.7425 \\
\hline $\mathrm{MgAg}$ & 21.919 & $\mathrm{Ag}=10.49$ & 10.2829 & $\mathrm{Mg}=11.429$ & $\mathrm{MgO}=40.304$ & 3.65 & 11.042 & 0.9661 \\
\hline $\mathrm{MgNi}_{2}$ & 18.181 & $\mathrm{Ni}=8.908$ & 6.5888 & $\mathrm{Mg}=5.0034$ & $\mathrm{MgO}=40.304$ & 3.65 & 11.042 & 2.2069 \\
\hline
\end{tabular}

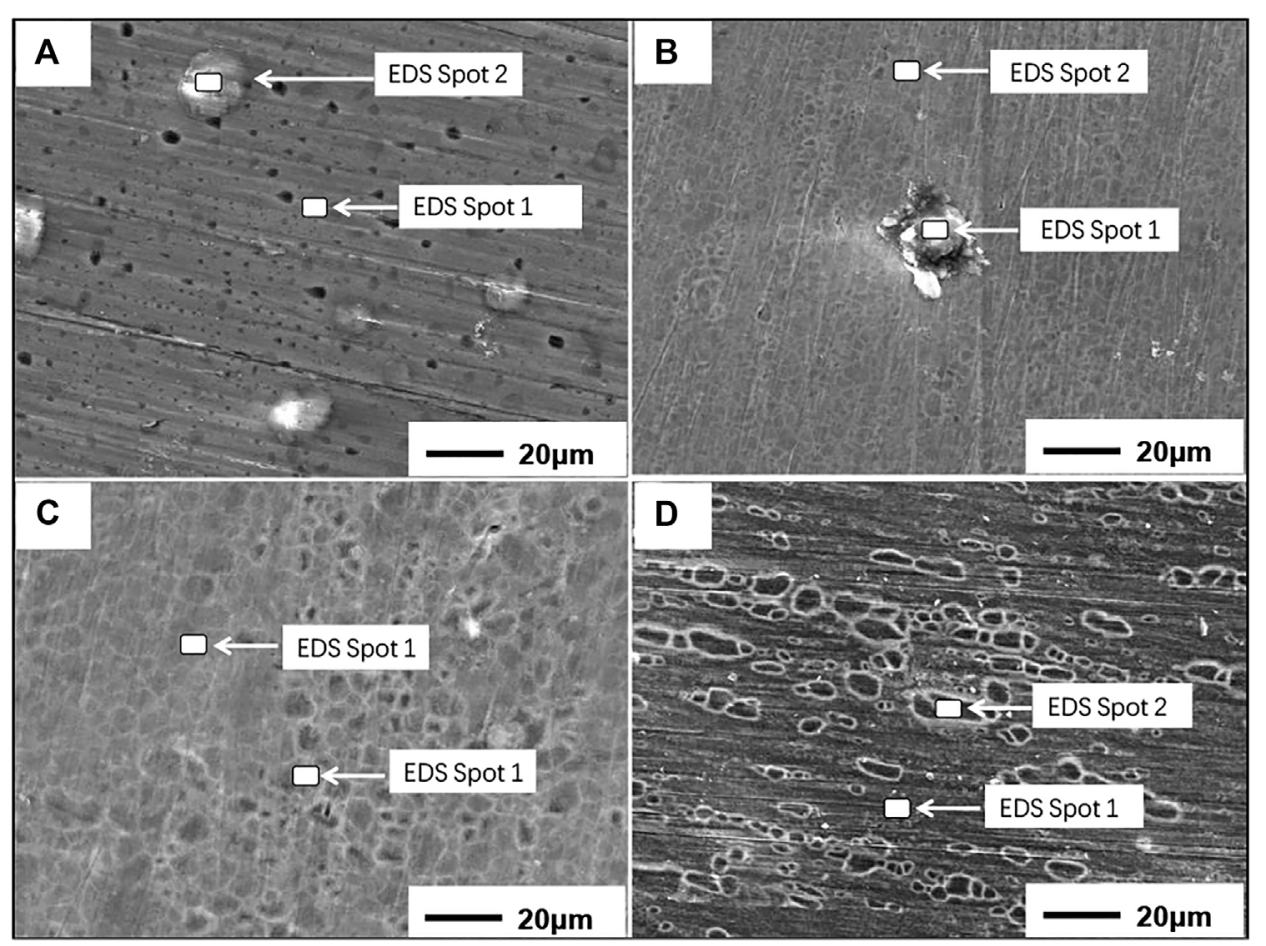

FIGURE 1 | The oxides morphologies of different samples: (A) pure Mg; (B) Mg-3Y; (C) Mg-5Y; (D) Mg-7Y.

extension of oxidation time (Zhou et al., 2013; Yu et al., 2016). Below $400-450^{\circ} \mathrm{C}$, the magnesium alloys have certain oxidation resistance, with a parabolic oxidation kinetics and intact oxide film (Yu et al., 2018). Once the temperature exceedes $400^{\circ} \mathrm{C}$, the oxidation reaction kinetics will change from parabolic to linear. The acceleration of oxidation reaction leads to the formation of film cracks on the surface. Therefore, in order to study the microstructure of the dense oxide films on $\mathrm{Mg}-\mathrm{Y}$ alloys, the oxidation temperature of $400^{\circ} \mathrm{C}$ was chosen. The thermo gravimetric analysis (TGA) was used to measure the weight increment of different samples. The heating rate was $10^{\circ} \mathrm{C} / \mathrm{min}$ in the air environment from room temperature to $500^{\circ} \mathrm{C}$.

As shown in Figure 1, the morphologies of oxide films formed on $\mathrm{Mg}-\mathrm{xY}(\mathrm{x}=0$, 3, 5, 7 wt.\%) samples are quite different. Many $\mathrm{MgO}$ particles and pores existed on the surface of pure $\mathrm{Mg}$, indicating a poor corrosion resistance of the oxide film. With the addition of $3 \mathrm{wt} . \% \mathrm{Y}$, the surface tended to be smooth and compact, and the pores were also disappeared. However, there 


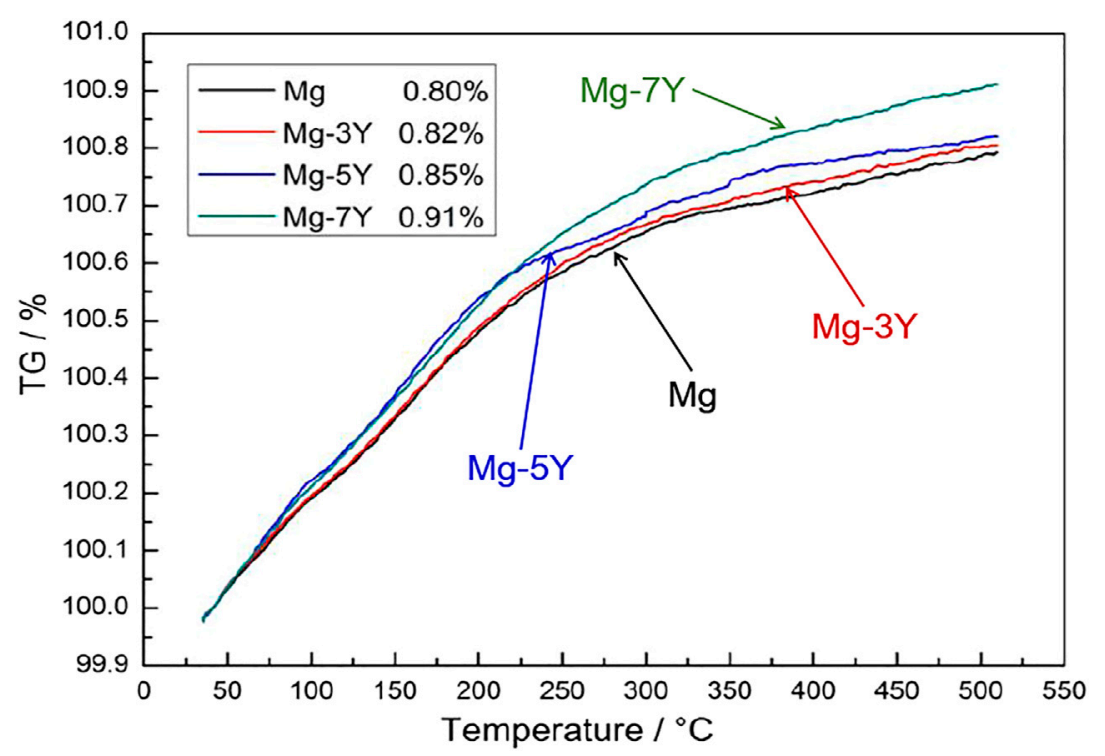

FIGURE 2 | The thermo gravimetric analysis results of different samples.

TABLE 4 | The EDS results of oxides of different materials.

\begin{tabular}{lcccc} 
Materials & Locations & \multicolumn{3}{c}{ Weight \% } \\
\cline { 3 - 5 } & & Element Mg $\boldsymbol{K}$ & Element O $\boldsymbol{K}$ & Element Y $\boldsymbol{K}$ \\
\hline Mg & Spot 1 & 98.4 & 1.6 & - \\
\multirow{2}{*}{ Mg-3Y } & Spot 2 & 95.6 & 4.4 & - \\
& Spot 1 & 71.5 & 15.6 & 12.8 \\
Mg-5Y & Spot 2 & 60.2 & 21.7 & 18.1 \\
& Spot 1 & 64.0 & 17.2 & 18.7 \\
Mg-7Y & Spot 2 & 53.0 & 22.5 & 24.5 \\
& Spot 1 & 57.0 & 21.4 & 21.6 \\
& Spot 2 & 55.6 & 23.2 & 21.2 \\
\hline
\end{tabular}

were still a small amount of $\mathrm{MgO}$ particles on the sample surface. With the increasing of $\mathrm{Y}$-content, $\mathrm{MgO}$ particles disappeared completely, whereas the squama-like oxides formed on the surface of Mg-5Y alloys. As the Y content increased to $7 \mathrm{wt} . \%$, the size of the squama-like oxides becomes larger, and the boundary of oxides turned clearly.

The EDS results of oxides on the surface of $\mathrm{Mg}-\mathrm{xY}(\mathrm{x}=0,3,5$, 7 wt.\%) samples are shown in Table 4. The Y-contents in the oxides are more than the matrix. Both the O-content and Y-content increased with the addition of Y element, whereas the Mg-content decreased. This phenomenon because that the activity of $\mathrm{Y}$ element is higher than $\mathrm{Mg}$ element. With the extension of oxidation time, the thickness of oxides increased. The oxidation rate of all the samples was reduced by the oxides barrier, which inhibited the inward diffusion of $\mathrm{O}_{2}$ and the outward diffusion of $\mathrm{Mg}^{2+}$. According to the calculation in Table 3, the PBR of $\mathrm{Y}_{2} \mathrm{O}_{3}$ formed from the $\mathrm{Mg}_{24} \mathrm{Y}_{5}$ unit cell was 1.1923, which indicated that the $\mathrm{Y}_{2} \mathrm{O}_{3}$ oxidation film was compact. Moreover, the chemical property of $\mathrm{Y}_{2} \mathrm{O}_{3}$ was relatively stable. Therefore, when $\mathrm{Mg}-\mathrm{Y}$ alloys were exposed in the high
TABLE 5 | The EDS mapping analysis of different samples.

\begin{tabular}{lcccc} 
Materials & Locations & \multicolumn{3}{c}{ Weight \% } \\
\cline { 3 - 5 } & & Element Mg $\boldsymbol{K}$ & Element $\mathbf{~ K ~}$ & Element Y $\mathbf{K}$ \\
\hline $\mathrm{Mg}$ & mapping & 97.5 & 2.5 & - \\
$\mathrm{Mg}-3 \mathrm{Y}$ & mapping & 65.1 & 13.8 & 21.1 \\
$\mathrm{Mg}-5 \mathrm{Y}$ & mapping & 62.1 & 14.1 & 23.8 \\
Mg-7Y & mapping & 57.0 & 16.1 & 26.9
\end{tabular}

temperature environment, the dense $\mathrm{MgO} / \mathrm{Y}_{2} \mathrm{O}_{3}$ composite oxide layers were formed on the sample surfaces. The composite oxide layer acted as a physical barrier to hinder the oxidation reaction, thus the oxidation of magnesium alloys was slowed down (Wang et al., 2008).

The TGA result was shown in Figure 2. From the trends of the curves in the figure, all samples had a fast oxidation rate at the initial stage. The oxidation reaction rate decreased with the prolong of oxidation reaction time and the rising of temperature. The Mg-5Y alloys had the faster oxide reaction rate than the pure $\mathrm{Mg}, \mathrm{Mg}-3 \mathrm{Y}$ and $\mathrm{Mg}-7 \mathrm{Y}$ samples at the initial stage of oxidation. Then, the thin, smooth and dense oxide films were formed on the surface of samples, the oxidation rates were all reduced. At the maximum temperature, the weight improvement ratio of pure $\mathrm{Mg}, \mathrm{Mg}-3 \mathrm{Y}, \mathrm{Mg}-5 \mathrm{Y}$ and $\mathrm{Mg}-7 \mathrm{Y}$ was $0.80,0.82,0.85$ and $0.91 \%$, respectively. This phenomenon indicated that $\mathrm{Y}$ element had the higher activity to bind with oxygen than $\mathrm{Mg}$.

According to the mapping results in Figure 3, the difference of $\mathrm{Y}$-content in Mg-xY ( $\mathrm{x}=3,5,7$ wt.\%) alloys led to the different elementary composition in the oxidation products.

As shown in Table 5, mapping analysis on the surface of pure magnesium showed that the $\mathrm{O}$ content was only $2.5 \%$. This 

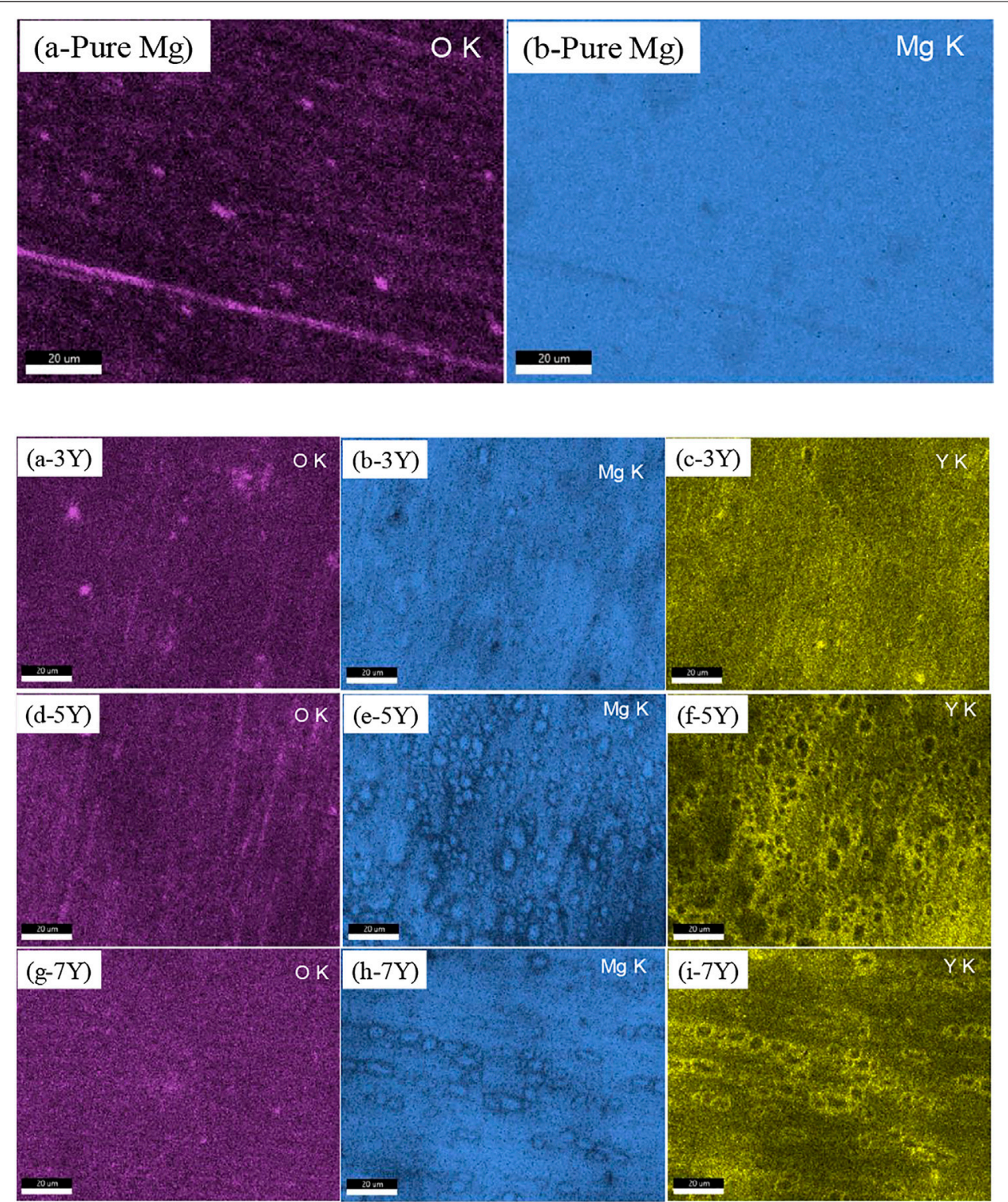

FIGURE 3 | The mapping results of elementary composition in the oxidation products on different samples surfaces: (a-pure Mg) and (b-pure Mg): pure Mg; (a-3Y) and (b-3Y) and (c-3Y): Mg-3Y; (d-5Y) and (e--5Y) and (f-5Y): Mg-5Y; (g-7Y) and (h-7Y) and (i-7Y): Mg-7Y.

phenomenon proved that the oxide film on the surface was very thin, so that the electron beam can penetrate the oxide film and reach the Mg matrix. The oxidation films of $\mathrm{Mg}-3 \mathrm{Y}$ samples were composed of $\mathrm{MgO}$ as the major constituent and minor $\mathrm{Y}_{2} \mathrm{O}_{3}$. When Y-content was $3 \mathrm{wt} . \%$, the average content of oxygen element in the surface mapping analysis was about $13.8 \mathrm{wt} . \%$, and the $\mathrm{Y}$ element was about $21.1 \mathrm{wt} . \%$, which indicated that a large number of $\mathrm{Y}_{2} \mathrm{O}_{3}$ were formed in the oxide film. The content of $\mathrm{Y}$ element was larger than that of in the alloy matrix without oxidation. With the increase of Y-content to $7 \mathrm{wt} . \%$, the $\mathrm{O}$ element on the surface film increased to $16.1 \mathrm{wt} . \%$, while the $\mathrm{Y}$ content increased to $26.9 \mathrm{wt} . \%$.

The average thicknesses of oxidation films for different samples were measured by backscattered electrons scanning spectroscopy, as shown in Figure 3. And the elemental composition at different cross-section locations was also analyzed by EDS, with results summarized in Table 6. In Figure 4 the average thickness of oxidation films on the surface of pure $\mathrm{Mg}$ was about $0.4 \mu \mathrm{m}$. With the addition of Y-content, the oxidation film thickness increased from $0.5 \mu \mathrm{m}$ (Mg-3Y) to more than $1.5 \mu \mathrm{m}$ (Mg-7Y). This phenomenon was attributed to the high activity of Y element, which preferentially combines with oxygen to form oxide films (Wang et al., 2009).

As shown in Table 6, all the oxidation films were consisted of $\mathrm{Y}_{2} \mathrm{O}_{3}$ and $\mathrm{MgO}$. For both pure $\mathrm{Mg}$ and $\mathrm{Mg}-\mathrm{xY}(\mathrm{x}=3,5$, $7 \mathrm{wt} . \%)$ alloys, the major content of the oxidation film is $\mathrm{MgO}$. However, the closer to the top surface of the oxide film, the larger amount of $\mathrm{Y}_{2} \mathrm{O}_{3}$-content. In general, the protection 
TABLE 6 | The elemental composition of different cross-section locations.

\begin{tabular}{lcccc}
\hline \multirow{2}{*}{ Materials } & Locations & \multicolumn{3}{c}{ Weight \% } \\
\cline { 3 - 5 } & & Element Mg $\boldsymbol{K}$ & Element O $\boldsymbol{K}$ & Element Y K \\
\hline Mg & Spot 1 & 92.8 & 7.2 & - \\
& Spot 2 & 95.2 & 4.8 & - \\
\hline Mg-3Y & Spot 3 & 99.3 & 0.7 & - \\
& Spot 1 & 41.9 & 28.7 & 29.4 \\
& Spot 2 & 44.8 & 25.7 & 29.5 \\
& Spot 3 & 74.6 & 16.5 & 8.8 \\
\hline \multirow{2}{*}{ Mg-5Y } & Spot 1 & 35.1 & 32.3 & 32.6 \\
& Spot 2 & 33.6 & 31.4 & 35.0 \\
& Spot 3 & 83.4 & 14.0 & 2.7 \\
\hline Mg-7Y & Spot 1 & 39.3 & 32.1 & 28.7 \\
& Spot 2 & 42.2 & 31.4 & 26.3 \\
& Spot 3 & 75.6 & 17.8 & 6.6 \\
\hline
\end{tabular}

performance of oxidation products to $\mathrm{a}-\mathrm{Mg}$ matrix was related the PBR of films covered on the samples, which determine the diffusion rate of metal atoms from metal/ oxide interface to oxide/air interface, and the diffusion rate of oxygen atoms from oxide/air interface to metal/oxide interface (Zhao et al., 2018). The inward diffusion of oxygen atoms and the outward diffusion of $\mathrm{Mg}$ atoms through the oxide films was suppressed due to the compact microstructure of $\mathrm{Y}_{2} \mathrm{O}_{3}$-content.
Figure 5 shows the open circuit potential of pure $\mathrm{Mg}$ and $\mathrm{Mg}$ $\mathrm{xY}$ alloys covered with oxidation films in $3.5 \% \mathrm{NaCl}$ solution. As time increased, all the ocp values decreased, due to the desquamation of oxidation films covered on the surface of samples (Jiang, et al., 2021). The OCP value of Mg-7Y alloy was the most positive, indicating the most alleviated local corrosion of $\mathrm{Mg}-7 \mathrm{Y}$ alloy among the samples. In addition, with the extension of immersion time, the OCP of $\mathrm{Mg}-\mathrm{Y}$ alloys tended to be stable, indicating a stabilized surface state. The electrochemical activity of the samples decreased in the order of Mg-7Y > Mg-5Y > Mg-3Y > pure Mg. The corrosion tendency of $\mathrm{Mg}-7 \mathrm{Y}$ was the lowest in the exposure of $3.5 \% \mathrm{NaCl}$ for $1200 \mathrm{~s}$, due to the protection of the thick and compact oxidation film.

The Tafel slopes of pure Mg and Mg-xY alloys covered with oxidation films measured in $3.5 \% \mathrm{NaCl}$ solution was shown in Figure 6. The corrosion reactions were identical according to the similarity of all the Tafel curves. As shown in Figure 6, the characteristic anode branches were generally sharp formation, which represented the dissolution of $\alpha-\mathrm{Mg}$. The cathodic hydrogen evolution was the main reaction, which determined the reaction rate of the electrochemical corrosion. When the potential was more negative than the pitting potential, the cathodic branch showed up linear Tafel characteristics. Therefore, the corrosion current density of pure $\mathrm{Mg}$ and $\mathrm{Mg}$ $\mathrm{xY}$ alloys was calculated by the tangent of linear cathode branch. The results of corrosion current density were shown in the table of Figure 6. Due to the different resistance of oxides films to the

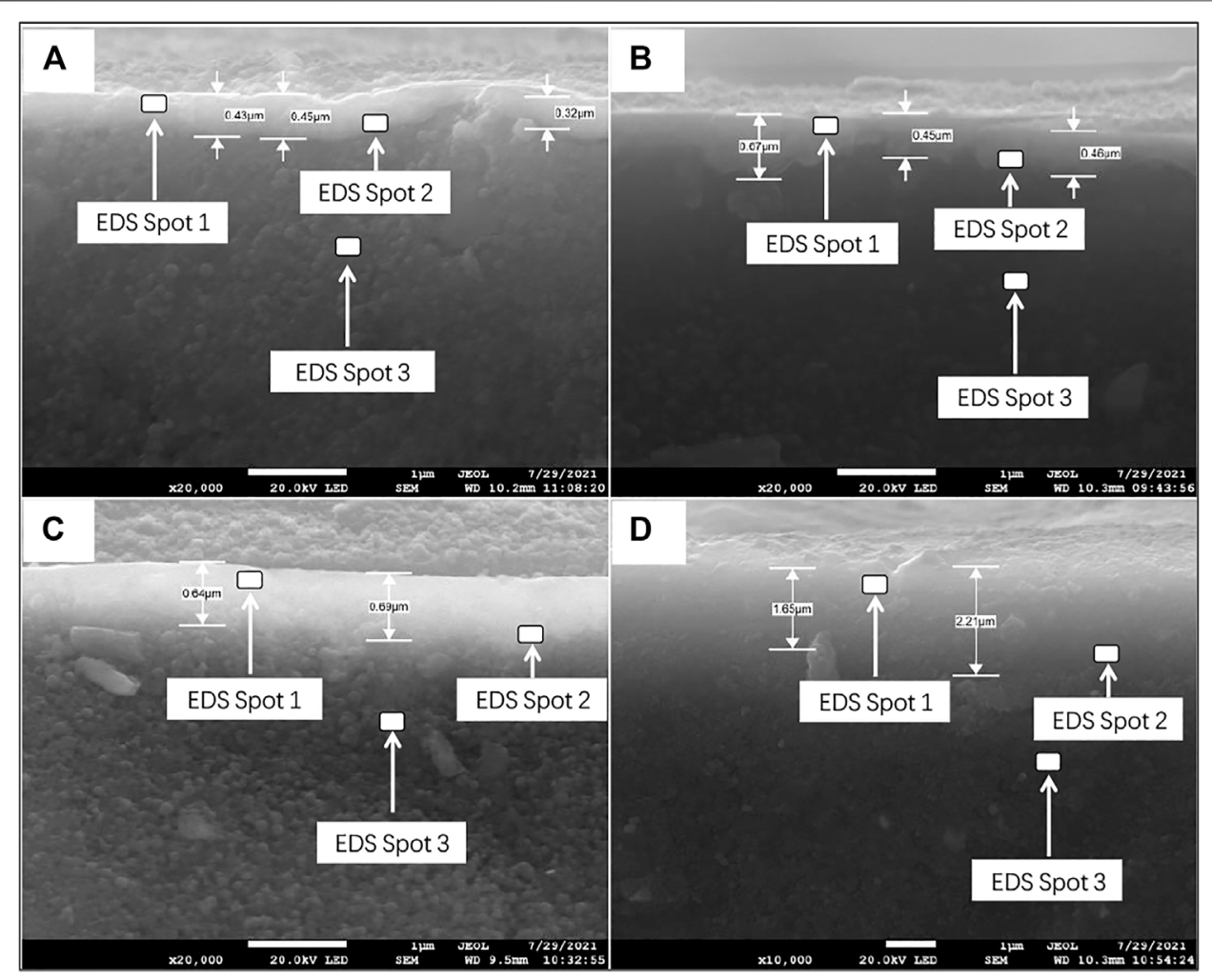

FIGURE 4 | The thicknesses of oxidation films on different samples measured by backscattered electrons: (A) pure Mg; (B) Mg-3Y; (C) Mg-5Y; (D) Mg-7Y. 


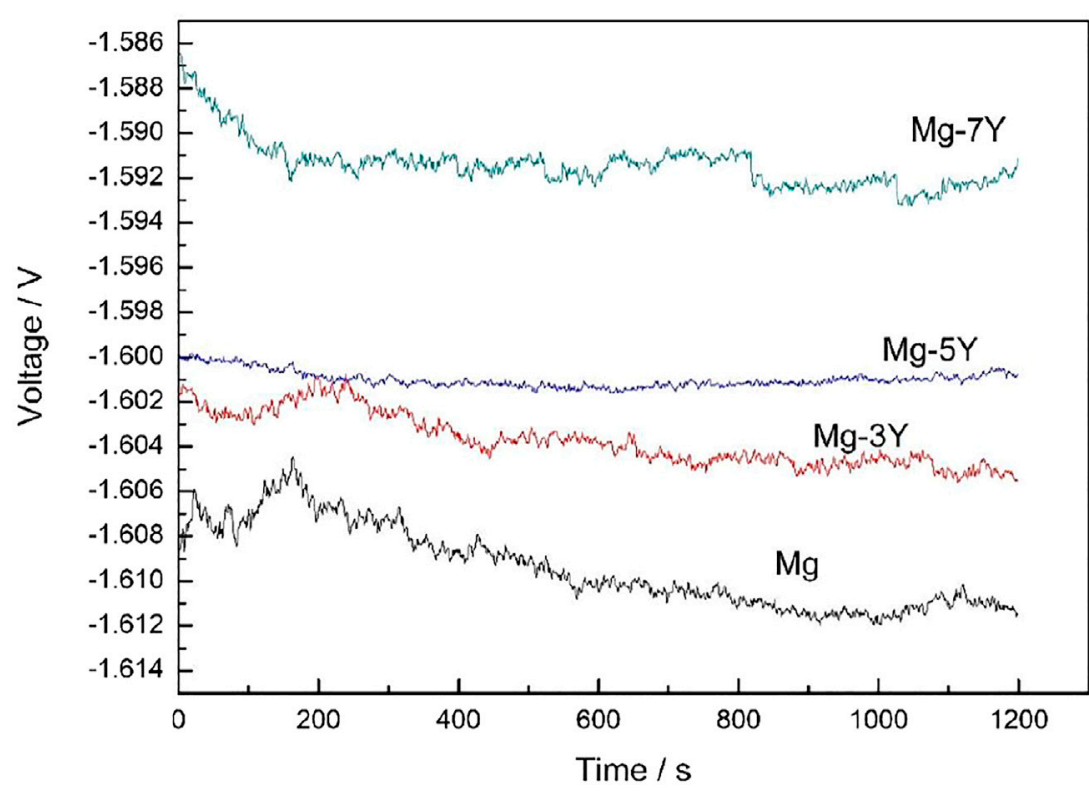

FIGURE 5 | The electrochemical open circuit potential of samples covered with oxidation films in the surface measured in $3.5 \%$ NaCl solution.

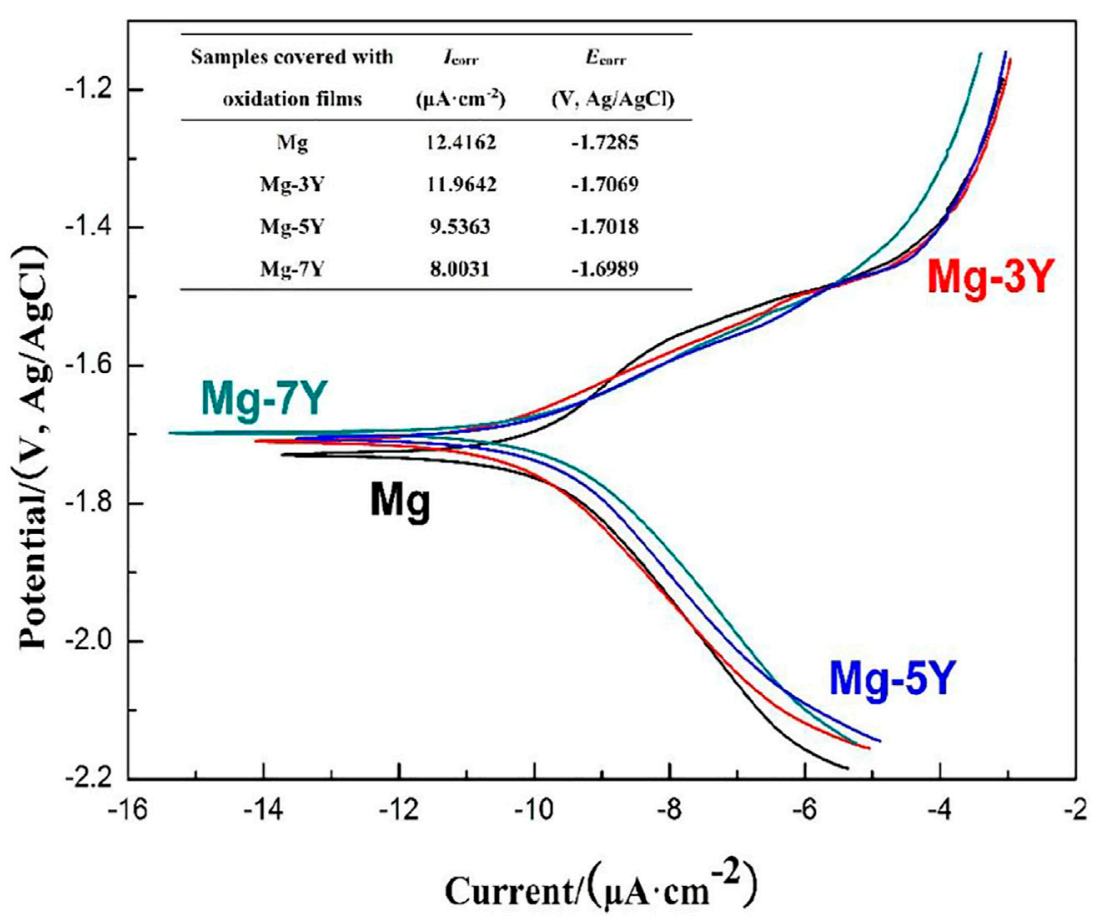

FIGURE 6 | The electrochemical Tafel slopes of samples covered with oxidation films in the surface measured in $3.5 \% \mathrm{NaCl}$ solution.

corrosion reaction, the pure $\mathrm{Mg}$ showed a largest $I_{\text {corr }}$, whereas the Mg-7Y alloy showed the smallest. The results depended on thickness and density of oxides films, which indicated that the oxides films formed in the surface of $\mathrm{Mg}-7 \mathrm{Y}$ alloy showed a best corrosion barrier effect.
The electrochemical impedance spectra curves of pure $\mathrm{Mg}$ and $\mathrm{Mg}-\mathrm{xY}$ alloys covered with oxidation films measured in 3.5\% $\mathrm{NaCl}$ solution was shown in Figure 7. The largest electrochemical impedance spectra of $\mathrm{Mg}-7 \mathrm{Y}$ alloy samples indicated that hydrogen evolution of the $\mathrm{a}-\mathrm{Mg}$ matrix reaction had the 


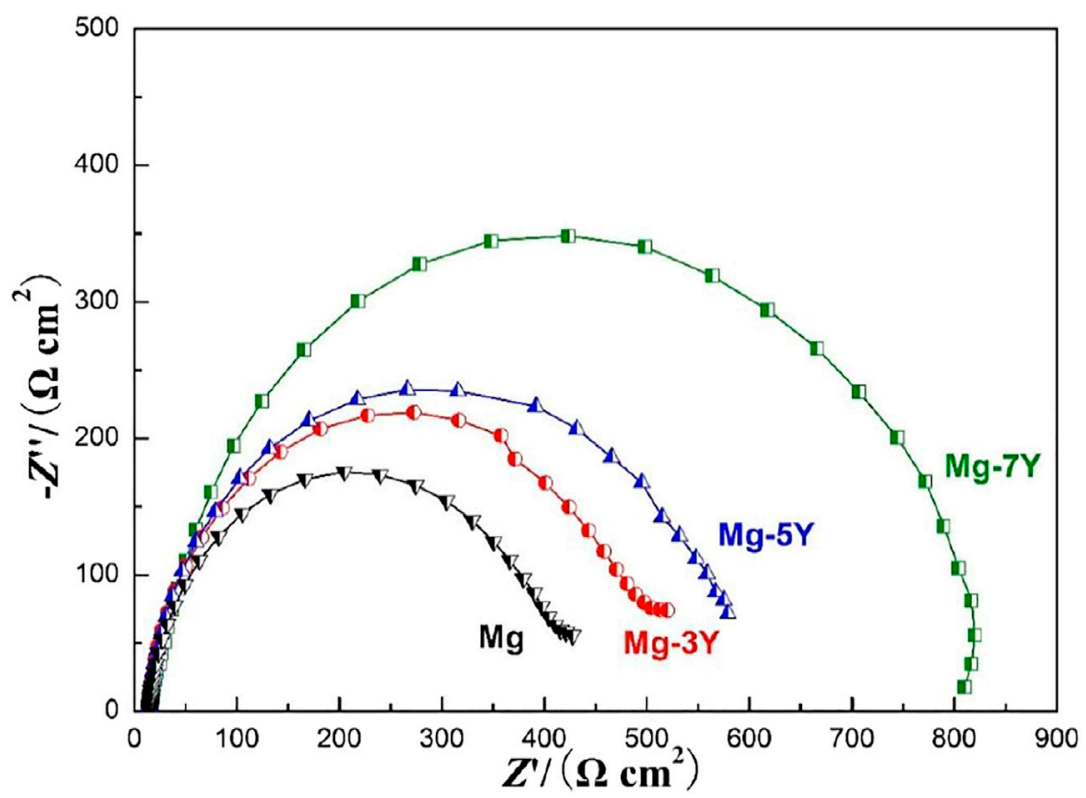

FIGURE 7 | The electrochemical impedance spectra curves of samples covered with oxidation films in the surface measured in $3.5 \%$ NaCl solution.

largest energy barrier. According to the results in Figure 6, the corrosion resistance can be ranked as follows: pure $\mathrm{Mg}<\mathrm{Mg}-3 \mathrm{Y}$ $<$ Mg-5Y $<$ Mg-7Y, which demonstrated that the tendency was consistent with the preceding data in this study. The electrochemical impedance spectra curves of different samples were different, which represented distinctive dynamic corrosion process. The larger of the PBR of oxides films, the stronger of the barrier effect on the ion diffusion of corrosion reaction. Therefore, the alloy with the most Y-content showed the best corrosion resistance.

PBR is the ratio of oxide volume generated from the combination of metal and oxygen on the metal surface to the volume of consumed metal atoms, which reflects the stress condition in the oxide film. The corrosion tendency of magnesium alloy is closely related to the conditions of oxide layer during oxidation. The PBR of $\mathrm{Y}_{2} \mathrm{O}_{3}$ films generated from $\mathrm{Mg}_{24} \mathrm{Y}_{5}$ was about 1.1923, which indicated the $\mathrm{Y}_{2} \mathrm{O}_{3}$ films were continuous and compact (Okamoto, 1992). Therefore, the content of Y-content increased, the corrosion tendency of $\mathrm{Mg}$ $\mathrm{Y}$ alloys decreased. When PBR is less than 1 or more than 2, tensile stress or excessive compressive stress exists in the oxide film, and the film is prone to rupture. The $\mathrm{PBR}$ value of $\mathrm{MgO} / \mathrm{Mg}$ was 0.81 , which indicated that the $\mathrm{MgO}$ layer had a large internal tensile stress, and the film structure was loose (Lin, et al., 2010; Qin, et al., 2016; Lee, et al., 2017). As a result, the pure Mg had the largest corrosion tendency than Mg-Y alloys.

As shown in Figure 8, the oxidation mechanism of pure $\mathrm{Mg}$ and $\mathrm{Mg}-\mathrm{Y}$ alloys in this study. With the increasing of Y-content, the amount and volume fraction of precipitated phases on grain boundary of Mg-Y binary alloys became larger before heat treatment. After the heat treatment, pure $\mathrm{Mg}$ reacted with $\mathrm{O}$ atom to form a loose porous oxide film in Figure 7A. For Mg-Y binary alloys, the $\mathrm{Y}$ atom bonded to the $\mathrm{O}$ atom preferentially, and then the $\mathrm{Mg}$ atom bonded to the $\mathrm{O}$ atom at the high temperatures. The $\mathrm{Y}_{2} \mathrm{O}_{3}$ and $\mathrm{MgO}$ products formed in the surface of different $\mathrm{Mg}-\mathrm{Y}$ binary alloys. With the increasing of $\mathrm{Y}$-content, the ratio of $\mathrm{Y}_{2} \mathrm{O}_{3}$ formed in the oxides became larger. Moreover, the volume and dimensions of $\mathrm{Y}_{2} \mathrm{O}_{3}$ also showed a large improvement. As the oxidation reaction processed, the equilibrium state of the interface between the alloy and the oxidation environment changed (You, et al., 2014). At the initial stage of oxidation, the equilibrium state of the alloy interface was alloy-oxidation environment. With the formation of oxidation films, the equilibrium state of the interface changed to alloy/oxidation products/oxidation environment. During the oxidation reaction, the PBR value of $\mathrm{MgO}$ products was only about 0.8 , which could not protect the $\mathrm{a}-\mathrm{Mg}$ matrix from the further corrosion reaction effectively. However, the PBR value of $\mathrm{Y}_{2} \mathrm{O}_{3}$ was larger than 1 , which improved the overall density of mixed oxide in the surface to a certain extent. Therefore, the protective effect of mixed oxide on the matrix was improved. This phenomenon indicated that the more of Y-content, the stronger the protective effect of oxide film on the $\alpha-\mathrm{Mg}$ matrix.

On the other hand, precipitated phases in the magnesium alloys often act as the cathode of microelectrochemical coupling reaction, accelerating the corrosion of $\alpha-\mathrm{Mg}$ matrix. With the alloying element increased gradually, more and more Y-content reacted with $\alpha-\mathrm{Mg}$ matrix, the number of precipitated phases also increased tremendously. However, In the heating process, the precipitated phases containing rare earths were easier to oxidize than the magnesium matrix. And then the $\mathrm{Y}_{2} \mathrm{O}_{3}$ formed have a better protection effect on the $\alpha-\mathrm{Mg}$ matrix. The more precipitated phases contained rare earth were, the more $\mathrm{Y}_{2} \mathrm{O}_{3}$ is oxidized, which resulted a improvement to the corrosion resistance of $\alpha-\mathrm{Mg}$ matrix. 


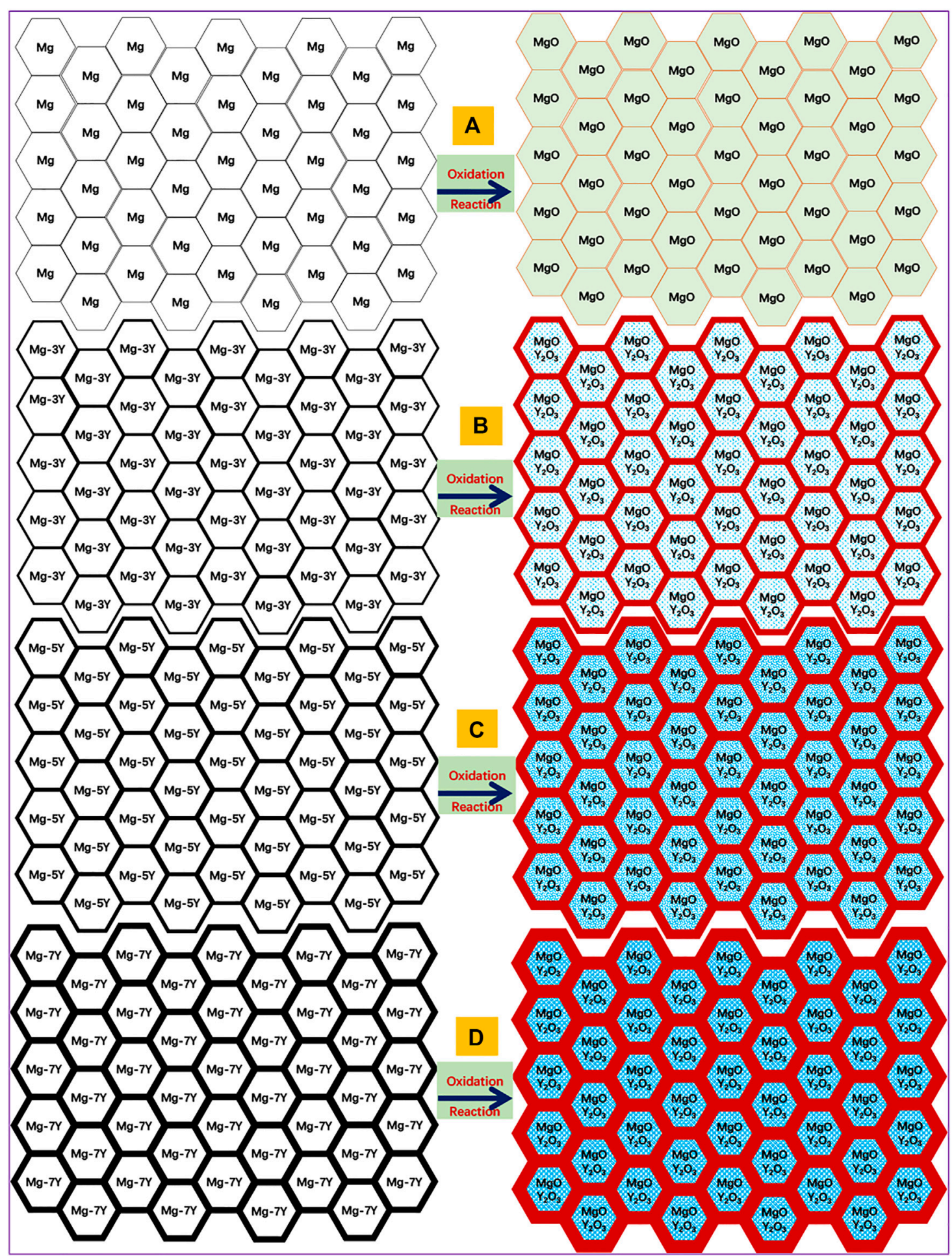

FIGURE 8 | The oxidation mechanism of pure Mg and Mg-Y alloys in this study.

In fact, different types of precipitated phases may exist in the same magnesium alloy. Moreover, one alloying element also may form different kinds of precipitated phases in the magnesium alloys with the changes of the alloying element content. In this work, the PBR values of the oxide film formed from the common precipitated phases in magnesium alloys were calculated. In the actual oxidation process of magnesium alloys, it is possible that multiple oxidation reactions occur simultaneously. This research 
is expected to provide guidance in the development of heatresistant magnesium alloys by adjusting the types of alloying elements and film formation from the precipitated phases.

\section{CONCLUSION}

1) The PBR values of preferentially oxides formed from $\mathrm{Mg}_{12} \mathrm{Nd}$ and $\mathrm{Mg}_{24} \mathrm{Y}_{5}$ were 1.0584 and 1.1923, respectively, which indicated a good protection for the $\mathrm{Mg}$ matrix. The PBR values of preferentially oxides formed from $\mathrm{Mg}_{3} \mathrm{Gd}$ and $\mathrm{MgNi}_{2}$ were larger than 2, which existed a compressive stress. The PBR values of preferentially oxides formed from $\mathrm{Mg}_{17} \mathrm{Al}_{12}, \mathrm{MgZn}_{2}, \mathrm{MgCu}_{2}, \mathrm{Mg}_{2} \mathrm{Ca}, \mathrm{Mg}_{12} \mathrm{Ce}$, and $\mathrm{MgAg}$ were less than 1 , which existed a tensile stress. Both compressive stress and tensile stress would lead the fracture of oxides. These PBR values of oxides indicated a poor protection of $\mathrm{Mg}$ matrix.

2) The oxide films formed on the surfaces of $\mathrm{Mg}-\mathrm{xY}(\mathrm{x}=3,5$, 7 wt.\%) samples were consisted of $\mathrm{Y}_{2} \mathrm{O}_{3}$ and $\mathrm{MgO}$. The formation of $\mathrm{Y}_{2} \mathrm{O}_{3}$ was caused by the oxidation of $\mathrm{Mg}_{24} \mathrm{Y}_{5}$. The PBR values of preferentially oxides formed from $\mathrm{Mg}_{24} \mathrm{Y}_{5}$ was 1.1923, and then increased the PBR of $\mathrm{MgO}$ formed from $\mathrm{Mg}$ matrix to a certain extent. The electrochemical experiments proved that the corrosion resistance of $\mathrm{Mg}-\mathrm{Y}$ alloys improved with the increasing of Y-content.

3) In the actual oxidation process, multiple oxidation reactions will occur simultaneously. The composition of oxide films on the surface of magnesium alloys are complex. This work is expected to give a scientific and reasonable method to improve intrinsic corrosion resistance of magnesium alloys by regulating the types of precipitates.

\section{REFERENCES}

Bradford, S. A. (1993). Oxidation: Metal-Gas Reactions, Corrosion Control. Boston, MA, US: Springer, 289-312. doi:10.1007/978-1-4684-8845-6_14

Chang, C. L., Lu, S., Fu, Y. Y., and Zhang, H. P. (2015). Flammability and the Oxidation Kinetics of the Magnesium Alloys AZ31, WE43, and ZE10. Corrosion Sci. 100, 177-185. doi:10.1016/j.corsci.2015.07.020

Cheng, S. L., Yang, G. C., Fan, J. F., Li, Y. J., and Zhou, Y. H. (2009). Effect of Ca and Y Additions on Oxidation Behavior of AZ91 alloy at Elevated Temperatures. Trans. Nonferrous Met. Soc. China 19, 299-304. doi:10.1016/S1003-6326(08) 60268-X

Czerwinski, F. (2002). The Oxidation Behaviour of an AZ91D Magnesium alloy at High Temperatures. Acta Mater. 50, 2639-2654. doi:10.1016/S1359-6454(02) 00094-0

Czerwinski, F. (2012). Oxidation Characteristics of Magnesium Alloys. JOM 64 (12), 1477-1483. doi:10.1007/s11837-012-0477-z

Czerwinski, F. (2015). The Reactive Element Effect on High-Temperature Oxidation of Magnesium. Int. Mater. Rev. 60 (5), 264-296. doi:10.1179/ 1743280415Y.0000000001

Fan, J. F., Yang, C. L., Han, G., Fang, S., Yang, W. D., and Xu, B. S. (2011). Oxidation Behavior of Ignition-Proof Magnesium Alloys with Rare Earth Addition. J. Alloys Comp. 509 (5), 2137-2142. doi:10.1016/j.jallcom.2010.10.168

James, G. S. (2005). Lange's Handbook of Chemistry. New York, NY MCGRAWHILL, 1.238-1.279.

Jiang, Q. T., Lu, D. Z., Wang, N., Wang, X. T., Zhang, J., Duan, J. Z., et al. (2021). The Corrosion Behavior of $\mathrm{Mg}-\mathrm{Nd}$ Binary Alloys in the Harsh marine Environment. J. Magnesium Alloys 9 (1), 292-304. doi:10.1016/ j.jma.2019.12.010

\section{DATA AVAILABILITY STATEMENT}

The original contributions presented in the study are included in the article/Supplementary Material, further inquiries can be directed to the corresponding author.

\section{AUTHOR CONTRIBUTIONS}

QJ and DL conceived and designed the study and experiment plan. CL performed the experiments. NL analyzed the energy dispersive spectrum datas. $\mathrm{BH}$ verified the experimental results. QJ wrote the paper. $\mathrm{DL}, \mathrm{CL}, \mathrm{NL}$, and $\mathrm{BH}$ reviewed and edited the manuscript. All authors read and approved the manuscript.

\section{FUNDING}

The present work was supported by National Natural Science Foundation of China for Exploring Key Scientific Instrument (No.41827805) and the Open Funds of the State Key Laboratory of Rare Earth Resource Utilization (No. RERU2021017) for providing support.

\section{ACKNOWLEDGMENTS}

The authors gratefully acknowledge professor Kui Zhang of State Key Laboratory for Fabrication and Processing of Nonferrous Metals.

Kaya, A. A. (2020). Review on Developments in Magnesium Alloys. Front. Mater. 7, 198. doi:10.3389/fmats.2020.00198

Lee, D. B., Abro, M. A., and You, B. S. (2017). High-temperature Oxidation of AZ91-0.3\%Ca-0.1\%Y alloy in Air. Met. Mater. Int. 23 (4), 720-725. doi:10.1007/s12540-017-6745-2

Lin, P. Y., Zhou, H., Sun, N., Li, W. P., Wang, C. T., Wang, M. X., et al. (2010). Influence of Cerium Addition on the Resistance to Oxidation of AM50 alloy Prepared by Rapid Solidification. Corrosion Sci. 52, 416-421. doi:10.1016/ j.corsci.2009.09.029

Liu, J., Li, Y., and Wang, F. (2009). The High Temperature Oxidation Behavior of Mg-Gd-Y-Zr alloy. Oxid Met. 71, 319-334. doi:10.1007/s11085-0099145-2

López, M. D., Múnez, C. J., Carboneras, M., Rodrigo, P., Escalera, M. D., and Otero, E. (2010). Influence of Temperature on Oxidation Behaviour of ZE41 Magnesium alloy. J. Alloys Comp. 491 (1/2), 131-136. doi:10.1016/ j.jallcom.2009.10.163

Mebarki, N., Ravi Kumar, N. V., Blandin, J. J., Suery, M., Pelloux, F., and Khelifati, G. (2005). Correlation between Ignition and Oxidation Behaviours of AZ91 Magnesium alloy. Mater. Sci. Technol. 21, 1145-1151. doi:10.1179/ $174328405 X 58904$

Medved, J., Mrvar, P., and Vončina, M. (2009). Oxidation Resistance of Cast Magnesium Alloys. Oxid Met. 71 (5/6), 257-270. doi:10.1007/s11085-009-9141-6 Nie, J. F. (2012). Precipitation and Hardening in Magnesium Alloys. Metall. Mater. Trans. A 43, 3891-3939. doi:10.1007/s11661-012-1217-2

Okamoto, H. (1992). Mg-Y (Magnesium-Yttrium). J. Phase Equilib. 13 (1), 105-106. doi:10.1007/BF02645395

Qin, L., Ding, J., Zhao, W. M., and Fang, Z. (2016). Oxidation Behavior and Surface Tension of Mg-1.2Ca alloy with Ce Addition. Rare Metal Mater. Eng. 45 (1), 23-27. doi:10.1016/S1875-5372(16)30039-X 
Shi, Z. Z., Chen, H. T., Zhang, K., Dai, F. Z., and Liu, X. F. (2020). Crystallography of Precipitates in Mg Alloys. J. Magnesium Alloys 9 (2), 416-431. doi:10.1016/ j.jma.2020.06.013

Song, X., Wang, Z. W., and Zeng, R. C. (2021). Magnesium Alloys: Composition, Microstructure and Ignition Resistance. Chin. J. Nonferrous Met. 31 (3), 598-622. doi:10.11817/j.ysxb.1004.0609.2021-40013

Sudholz, A. D., Gusieva, K., Chen, X. B., Muddle, B. C., Gibson, M. A., and Birbilis, N. (2011). Electrochemical Behaviour and Corrosion of Mg-Y Alloys. Corrosion Sci. 53 (6), 2277-2282. doi:10.1016/j.corsci.2011.03.010

Tan, Q., Atrens, A., Mo, N., and Zhang, M.-X. (2016). Oxidation of Magnesium Alloys at Elevated Temperatures in Air: A Review. Corrosion Sci. 112, 734-759. doi:10.1016/j.corsci.2016.06.018

Van Orman, J. A., and Crispin, K. L. (2010). Diffusion in Oxides. Rev. Mineralogy Geochem. 72 (1), 757-825. doi:10.2138/rmg.2010.72.17

Wang, X. M., Zeng, X. Q., Wu, G. S., Yao, S. S., and Li, L. B. (2007). Surface Oxidation Behavior of MgNd Alloys. Appl. Surf. Sci. 253 (22), 9017-9023. doi:10.1016/j.apsusc.2007.05.023

Wang, X. M., Zeng, X. Q., Zhou, Y., Wu, G. S., Yao, S. S., and Lai, Y. J. (2008). Early Oxidation Behaviors of Mg-Y Alloys at High Temperatures. J. Alloys Comp. 460 (1), 368-374. doi:10.1016/j.jallcom.2007.06.065

Wang, X. M., Wu, W. D., Tang, Y. J., Zeng, X. Q., and Yao, S. S. (2009). Early High Temperature Oxidation Behaviors of Mg-10Gd-3Y Alloys. J. Alloys Comp. 474 (1/2), 499-504. doi:10.1016/j.jallcom.2008.06.122

Xu, C., and Gao, W. (2000). Pilling-Bedworth Ratio for Oxidation of Alloys. Mater. Res. Innov. 3, 231, 235. doi:10.1007/s100190050008

You, B.-S., Park, W.-W., and Chung, I.-S. (2000). The Effect of Calcium Additions on the Oxidation Behavior in Magnesium Alloys. Scripta Mater. 42, 1089, 1094. doi:10.1016/S1359-6462(00)00344-4

You, B. S., Kim, Y. M., Yim, C. D., and Ha, S. K. (2014). "Oxidation and Corrosion Behavior of Non-flammable Magnesium Alloys Containing , Ca and Y," in Magnesium Technology. Editors M. Alderman, M. V. Manuel, N. Hort, and N. R. Neelameggham (New York, US: John-wiley), 325-329. doi:10.1002/ 9781118888179.ch62

Yu, X. W., Jiang, B., Yang, H., Yang, Q. S., Xia, X. S., and Pan, F. S. (2015). High Temperature Oxidation Behavior of Mg-Y-Sn, Mg-Y, Mg-Sn Alloys and its
Effect on Corrosion Property. Appl. Surf. Sci. 353, 1013-1022. doi:10.1016/ j.apsusc.2015.07.011

Yu, X., Shen, S., Jiang, B., Jiang, Z. T., Yang, H., and Pan, F. S. (2016). The Effect of the Existing State of $\mathrm{Y}$ on High Temperature Oxidation Properties of Magnesium Alloys. Appl. Surf. Sci. 370, 357-363. doi:10.1016/j.apsusc.2016.02.156

Yu, X. W., Jiang, B., He, J. J., Liu, B., and Pan, F. S. (2018). Oxidation Resistance of $\mathrm{Mg}$-Y Alloys at Elevated Temperatures and the protection Performance of the Oxide Films. J. Alloys Comp. 749, 1054-1062. doi:10.1016/j.jallcom.2018.03.342

Zhao, X. Y., Ning, Z. L., Li, Z. Q., Zou, W. B., Li, B. H., He, K., et al. (2018). In-mold Oxidation Behavior of Mg-4.32Y-2.83Nd-0.41Zr alloy. J. Mater. Sci. 53 (15), 11091-11103. doi:10.1007/s10853-018-2271-y

Zhou, N., Zhang, Z. Y., Dong, J., Jin, L., and Ding, W. J. (2013). Selective Oxidation Behavior of an Ignition-Proof Mg-Y-Ca-Ce alloy. J. Rare Earths 31 (10), 1003-1008. doi:10.1016/S1002-0721(13)60021-6

Zhu, C. Y., and Chen, B. (2019). Atomic Scale Investigation on Precipitates and Defects of Mg-RE Alloys: a Review. Adv. Eng. Mater. 21 (3), 1800734. doi:10.1002/adem.201800734

Conflict of Interest: The authors declare that the research was conducted in the absence of any commercial or financial relationships that could be construed as a potential conflict of interest.

Publisher's Note: All claims expressed in this article are solely those of the authors and do not necessarily represent those of their affiliated organizations, or those of the publisher, the editors and the reviewers. Any product that may be evaluated in this article, or claim that may be made by its manufacturer, is not guaranteed or endorsed by the publisher.

Copyright (C) 2021 Jiang, Lu, Liu, Liu and Hou. This is an open-access article distributed under the terms of the Creative Commons Attribution License (CC BY). The use, distribution or reproduction in other forums is permitted, provided the original author(s) and the copyright owner(s) are credited and that the original publication in this journal is cited, in accordance with accepted academic practice. No use, distribution or reproduction is permitted which does not comply with these terms. 